\title{
The Effect of Compensation and Work Loads Towards Intension of Turnover with Work Satisfaction as a Variable Mediation in Clinic Employees of PT Nayaka Era Husada Branch of Bekasi
}

\author{
Thia Dwi Agustine ${ }^{1}$ \\ Mercu Buana University, Jakarta
}

\author{
Lenny Christina Nawangsari ${ }^{2}$ \\ Mercu Buana University, Jakarta
}

\begin{abstract}
This study aims to examine the effect of compensation and workload on turnover intention in the clinical team of PT Nayaka Era Husada Bekasi region with job satisfaction as an intervening variable. The instrument used in this study was a questionnaire to 60 respondents who were further analyzed descriptively and quantitatively. Descriptive analysis in this study is used to provide an overview of the characteristics of respondents and an overview of research variables while quantitative analysis conducted with SEM-PLS (Partial Least Square) analysis techniques will be used to test the hypotheses in this research. Based on the results of the analysis in this study, the result shows that compensation has a positive significant effect on job satisfaction, workload has a positive significant effect on job satisfaction, job satisfaction has a negative significant effect on turnover intention, compensation has a negative significant effect on turnover intention, and workload has a negative significant effect on turnover intention. In addition, the analysis also shows that job satisfaction is agood mediator because compensation and workload are proven to have a negative and significant effect on turnover intention through job satisfaction as an intervening variable.
\end{abstract}

Compensation is the most influential variable on turnover intention. In addition, the analysis also shows that job satisfaction is agood mediator because compensation and workload are proven to have a negative and significant effect on turnover intention through job satisfaction as an intervening variable. Compensation is the most influential variable on turnover intention. In addition, the analysis also shows that job satisfaction is agood mediator because compensation and workload are proven to have a negative and significant effect on turnover intention through job satisfaction as an intervening variable. Compensation is the most influential variable on turnover intention.

Keywords:- Compensation, Workload, Job Satisfaction, Turnover Intention.

\section{INTRODUCTION}

In the current era of globalization, an organization must continue to have human resources who are ready to face change. In the context of the service industry, especially medical, human resources play an important role as the main assets driving the life wheel of the organizationGood organizational performance can be damaged directly or indirectly by various employee behaviors. One form of employee behavior is turnover intention which can lead to the employee's decision to leave his job (Manurung, 2012).

Turnover Intention can be interpreted as the intention of a worker leaving the organization. Employees will start looking for other job alternatives and will stop working if these other alternatives are felt better than the current job.

Another reason on which this research is based is the high employee turnover rate of the last three years. It is known that the number of employees resigning from year to year is increasing. In 2016, the percentage of clinic employees who resigned was $32.7 \%$. Then in 2017 it was $33.3 \%$ and in 2018 it would increase to $34.3 \%$. This increase in turnover needs serious attention.

Based on the pre-survey results, the main reason for clinic employees to look for other jobs is dissatisfaction with the compensation received. Employees feel there is a mismatch between the compensation received and the workload obtained so that there is dissatisfaction with their work. Compensation, workload and work dissatisfaction that ultimately affect turnover intention.

From the results of the second phase of the pre-survey, only $35 \%$ of respondents were satisfied with the compensation received, while another $65 \%$ were dissatisfied with the compensation received. Then as many as $55 \%$ of respondents also feel that the workload is too heavy. And only $45 \%$ of respondents feel satisfaction at work. 


\section{LITERATURE REVIEW}

\section{A. Turnover Intention}

Turnover is the speed at which employees leave a company that varies prominently between industries (Dessler, 2011). Turnover intention is defined as the degree to which the respondent intends to leave or stay at their organization (Green et al. 2011).

According to Mobley on Dwiyan (2011), there are three indicators that can be used to measure turnover intention, namely:

a. Thoughts of quitting. Employees think of leaving the company because it starts from not being fulfilled their needs so as to create dissatisfaction in the work felt by the employee.

b. Intention to quit.Employees have a desire to leave the company because there is a feeling of discomfort in the current working conditions.

c. Intention to search for another job.Employees take action to find other jobs that he thinks are better and more comfortable, so that employees will leave the company if they get a new job.

\section{B. Compensation}

Compensation is the human resource management function that deals with every type of reward of individuals receive in exchange for performing organization tasks (Ivancevich and Konopaske, 2013). Compensation is all forms of payment or gifts for employees who come from their work (Dessler, 2011). Compensation is something that is received by employees as a substitute for their service contribution to the company (Rivai and Sagala, 2009).

According to Dessler (2011) indicators that can be used to measure compensation are as follows:

1. Direct Compensation.

a. Employees satisfied with overall salary

b. Employees get incentives according to applicable policies

c. Employees get bonuses according to their performance

2. Indirect Compensation.

a. Employees are satisfied with the health insurance facilities provided

b. Employees feel safe with retirement benefits

c. Employees feel safe with labor insurance

\section{Workload}

These burdens depend on how the person works. From the point of view of ergonomics, each workload received by a person must be suitable and balanced both with physical abilities, cognitive abilities and the limitations of humans who receive these burdens (Munandar, 2001 in Prihantoro, 2015). Workload is the average activity frequency of each job within a certain period (Irwandy, 2007).
According to Putra (2012) indicators that can be used to measure workload are as follows:

a. Target which is must be achieved. An individual's view of the amount of work targets given to complete his work, for example to input data, search for medical records, input diagnoses and so on. The view of the work that must be completed within a certain period.

b. Working Conditions. Includes about how the views held by individuals about the conditions of work, for example, overcoming unexpected events during service, or doing extra work outside the specified time.

c. Use of Work Time. The time spent in activities that are directly related to work.

d. Job Standards.An impression that an individual has about his work, for example a feeling that arises regarding the workload that must be resolved within a certain period

\section{Job satisfaction}

Job satisfaction is a pleasureable emotional state resulting from the appraisal of one's job or job experiences (Colquitt et al, 2009). Job satisfaction is the result of employees' perceptions about how well their work provides what is considered important (Luthans, 2011).Job satisfaction is a positive feeling of work that results from an evaluation of its characteristics (Robbins and Judge 2015).

Luthans (2011) suggested several indicators that can be used to measure job satisfaction, including:

a. Job itself. Job satisfaction itself is a major source of satisfaction, where the job provides interesting assignments, career opportunities, opportunities to accept responsibility and progress for employees

b. Income (salary). Salary as a multidimensional factor in job satisfaction is the amount of wages or money received and the level at which this can be seen as appropriate compared to others in the organization. Money not only helps people who get basic needs, but also tools to provide satisfaction needs at a higher level.

c. Promotion. Promotional opportunities are opportunities for advancement in the organization, apparently having a different effect on job satisfaction. This is because promotions have a number of different forms and have rewards, such as promotions based on seniority or performance and promotion of salary increases.

d. Supervision. Supervision is the ability of a supervisor (supervisor) to provide technical assistance and behavioral support.

e. Co-workers. In general, cooperative coworkers are the simplest source of job satisfaction for individual employees. Working groups, especially strong teams act as a source of support, comfort, advice and assistance to individual members. Because working groups require interdependence among members in completing work. Such conditions can be a positive effect on job satisfaction. 


\section{CONCEPTUAL FRAMEWORK}

Based on the results of previous studies, it can be concluded that the framework of this study can be presented in the figure as follows:

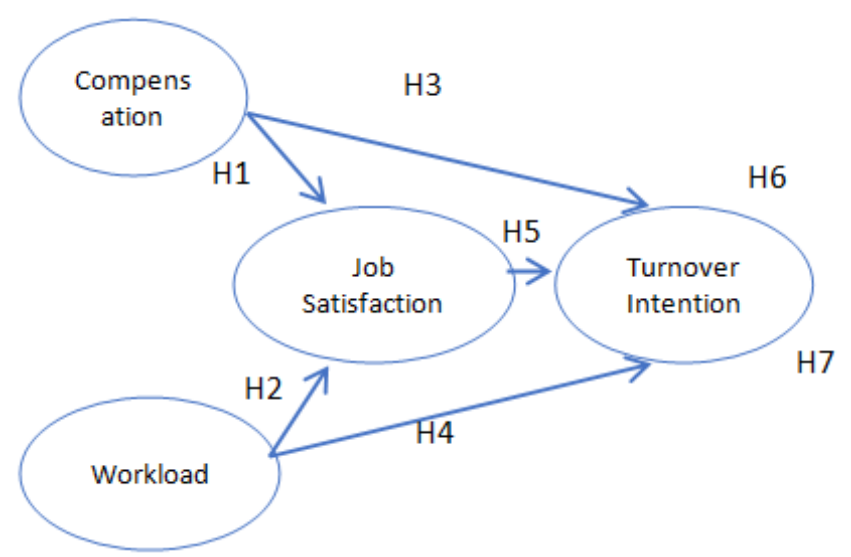

Fig 1:- Conceptual Framework

\section{$>\quad$ Research Hypothesis}

H1: Compensation affects job satisfaction

$\mathrm{H} 2$ : Workload affects job satisfaction

$\mathrm{H} 3$ : Compensation affects turnover intention

H4: Workload influences turnover intention.

H5: Job satisfaction affects turnover intention

H6:Compensation affects turnover intention through job satisfaction

H7: Workload influences turnover intention through job satisfaction

\section{RESEARCH METHODOLOGY}

\section{A. Samples and Populations}

The population in this study were all clinic employees of PT Nayaka Era Husada Bekasi Branch as many as 137 people. To determine the sample size, the authors used the Slovin technique with the results being 60 samples.

\section{B. Method of Collecting Data}

Types and sources of data used in this study are primary data and secondary data.The primary data source of this study was obtained directly in the field by distributing questionnaires while for secondary data in this study sourced from various books, journals, theses, articles and company data relating to research material.

\section{Data Analysis Method}

This study uses an analysis method with Structural Equation Modeling (SEM), with testing instruments using the Partial Least Square (PLS) method. The steps in the analysis with PLS are explained by Ghozali and Latan (2015), namely by evaluating the outer model and by the inner model.

\section{RESULTS AND DISCUSSION}

\section{A. Descriptive Analysis of Respondents}

The 60 respondents who were employees of the clinic of PT Nayaka Era Husada Bekasi branch. The gender of respondents is more female in composition, namely 42 respondents $(68.9 \%)$. While based on age, 17 respondents $(29.5 \%)$ were aged between 21-25 years, 16 respondents (26.2\%) were $26-30$ years old, 16 respondents $(26.2 \%)$ were 31-35 years old, 7 respondents $(11.5 \%)$ aged $36-40$ years and 4 respondents $(6.6 \%)$ aged over 41 years.

\section{B. Testing Model Measurement (Outer Model)}

The evaluating convergent validity by examining Average Variance Extracted (AVE), which is describing the magnitude of variance or diversity of manifest variables that can be owned by latent constructs, the greater the variance or diversity of variable manifests that can be contained by latent constructs, the greater the representation of variable manifests towards its latent construct.Evaluation of convergent validity from the examination of Average Variance Extracted (AVE) can be seen from the value of AVE based on the results of data processing with SmartPLS version 3.2.8.

\begin{tabular}{|c|c|}
\hline Variable & AVE \\
\hline Compensation & 0701 \\
\hline Workload & 0717 \\
\hline Job Satisfaction & 0710 \\
\hline Turnover & 0.693 \\
\hline
\end{tabular}

Table 1:- Average Variance Extracted (AVE)

AVE values in the table above for all variables have a AVE value $>0.5$ that is 0.701 for the compensation variable, 0.717 for the workload variable, 0.710 for the job satisfaction variable, and 0.693 for the turnover intention variable. Evaluation of convergent validity from the examination of internal consistency reliability can be seen from the value of Cronbach's Coefficient Alpha and Composite Reliability (CR) shown through the following table:

\begin{tabular}{|c|c|c|}
\hline Variable & $\begin{array}{c}\text { Cronbach's } \\
\text { Coefficient } \\
\text { Alpha }\end{array}$ & $\begin{array}{c}\text { Composite } \\
\text { Reliability } \\
\text { (CR) }\end{array}$ \\
\hline Compensation & 0.914 & 0.933 \\
\hline Workload & 0868 & 0.910 \\
\hline Job Satisfaction & 0.959 & 0.964 \\
\hline Turnover & 0.911 & 0.931 \\
\hline
\end{tabular}

Table 2: -Composite Reability (CR)

In the table above it can be concluded that the Cronbach's Coefficient Alpha value and the Composite Reliability value for all research variables are more than 0.80 or even close to 1 . This value has exceeded the standard, so that all variables in this study are declared reliable. 


\section{Evaluation of Structural Model (Inner Model)}

\section{R-Square Value}

To evaluate the $\mathrm{R}^{2}$ value based on the calculation results using calculate SmartPLS version 3.2.8 algorithm, the $\mathrm{R}^{2}$ value is 0.716 for the job satisfaction variable and 0.910 for the turnover intention variable. The value of $R^{2}$ shows that the level of determination of exogenous variables (compensation and workload) towards the endogenous is quite high.

\section{Goodness of Index (GoF)}

$G o F=\sqrt{A V E \times R^{2}}$

$G o F=\sqrt{0,705 \times 0,325}$

$G o F=\sqrt{0,229}$

$G o F=0.478$

$\mathrm{AVE}=(0.701+0.717+0.710+0.693) / 4=0.705$

R square $=(0.716 \times 0.910) / 2=0.325$

The results of the Goodness of Fit Index (GoF) calculation showed a value of 0.478 . According to Tenenhau (2004), the value of small $\mathrm{GoF}=0.1$, medium $\mathrm{GoF}=0.25$, and large $\mathrm{GoF}=0.36$. Based on these results it can be concluded that the combined performance of the measurement model (outer model) and structural model (inner model) as a whole is good because the Goodness of Fit Index (GoF) value is 0.478 .

\section{Predictive Relevance Testing (Q2)}

The purpose of testing predictive relevance $(\mathrm{Q} 2)$ is to validate the model. The results of the Q2 calculation are as follows:

$$
\begin{aligned}
& \mathrm{Q} 2=1-(1-\mathrm{R} 12)(1-\mathrm{R} 22) \\
& \mathrm{Q} 2=1-(1-0.716)(1-0.910) \\
& \mathrm{Q} 2=1--(0.284)(0.090) \\
& \mathrm{Q} 2=1-0.025 \\
& \mathrm{Q} 2=0.975
\end{aligned}
$$

Based on the predictive relevance (Q2) calculation above, it shows a value of 0.975 . In this research model, endogenous latent variables have predictive relevance $(\mathrm{Q} 2)$ values greater than 0 (zero) so that exogenous latent variables as explanatory variables are able to predict their endogenous variables, namely turnover intention variables or in other words prove that this model is considered to have predictive relevance the good one.

\section{Hypothesis Testing Results}

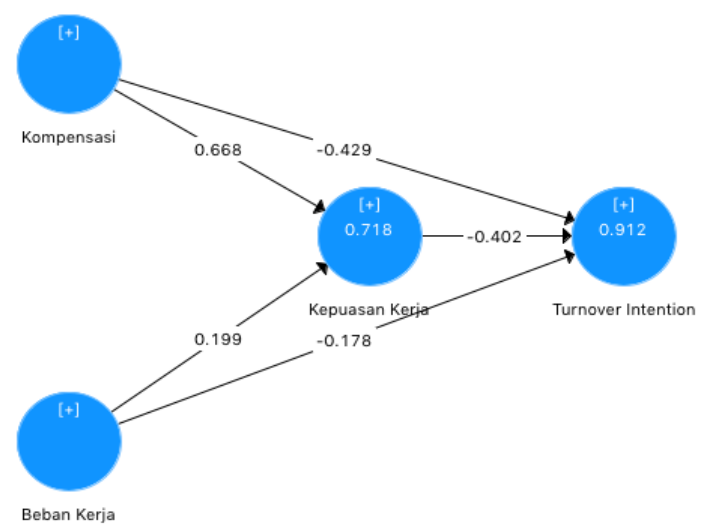

Fig 2:- Path coefficient model and t-statistics research model

\begin{tabular}{|l|l|l|l|}
\hline Direct Influence & $\begin{array}{l}\text { Original } \\
\text { Sample } \\
(\mathbf{O})\end{array}$ & $\begin{array}{l}\text { T } \\
\text { Statistics }\end{array}$ & Values \\
\hline $\begin{array}{l}\text { Compensation } \rightarrow \\
\text { Turnover Intention }\end{array}$ & -0.427 & 3,332 & 0.001 \\
\hline $\begin{array}{l}\text { Workload } \rightarrow \\
\text { Turnover Intention }\end{array}$ & -0.175 & 1986 & 0.048 \\
\hline $\begin{array}{l}\text { Compensation } \rightarrow \text { Job } \\
\text { Satisfaction }\end{array}$ & 0.666 & 6,850 & 0,000 \\
\hline $\begin{array}{l}\text { Workload } \rightarrow \text { Job } \\
\text { Satisfaction }\end{array}$ & 0.201 & 2,077 & 0.038 \\
\hline $\begin{array}{l}\text { Job Satisfaction } \rightarrow \\
\text { Turnover Intention }\end{array}$ & $-0,406$ & 2,921 & 0.004 \\
\hline \multicolumn{2}{|c|}{ Table 3 } & \\
\hline
\end{tabular}

Structural Equation:

$Z=0.666 X_{1}+0.201 X_{2}+e, R^{2}$ Adjusted $=0.706$; $\mathrm{Y}=(-0,427) \mathrm{X}_{1}+(-0,175) \mathrm{X}_{2}+(-0,406) \mathrm{Z}+\mathrm{e}, \mathrm{R}^{2}$ Adjusted $=0.905$;

1. It is known that the value of $t$ statistics is 6.850 which is greater than the value of $t$ table $=2.003$ and the value of P-Values $=0.000$ which is smaller than $\alpha=0.05$, meaning that Ha is accepted, so there is an influence of the Compensation variable $\left(\mathrm{X}_{1}\right)$ on Job Satisfaction $\left(\mathrm{Y}_{1}\right)$.

2. It is known that the value of $t$ statistics is 2.077 which is greater than the value of $t$ table $=2.003$, and the value of P-Values $=0.038$ which is smaller than $\alpha=0.05$, meaning that $\mathrm{Ha}$ is accepted, that is, there is an influence of the workload $\left(\mathrm{X}_{2}\right)$ variable on job satisfaction $\left(\mathrm{Y}_{1}\right)$. 
3. It is known that the value of t statistics is 3.332 which is greater than the value of $t$ table $=2.003$, and the value of P-Values $=0.001$ which is smaller than $\alpha=0.05$, meaning that $\mathrm{Ha}$ is accepted, that is, there is an influence of the compensation variable $\left(\mathrm{X}_{1}\right)$ on turnover intention $\left(\mathrm{Y}_{2}\right)$.

4. Given T Statistics Value of 1.986 Which Is Smaller Than $\mathrm{T}$ Table Value $=2.003$, And P-Values Value $=0.048$ Which Is Smaller Than $\alpha=0.05$, Meaning Ha Is Rejected,and there is no influence between workload $\left(\mathrm{X}_{2}\right)$ toturnover intention $\left(\mathrm{Y}_{2}\right)$.

5. The known T-value of 2.921 is greater than the value of $t$ table $=2.003$, and the value of P-Values $=0.004$ is smaller than $\alpha=0.05$, meaning that Ha is accepted, that is, there is an effect of the variable job satisfaction $\left(\mathrm{Y}_{1}\right)$ on turnover intention $\left(\mathrm{Y}_{2}\right)$.

\begin{tabular}{|c|c|c|c|c|}
\hline $\begin{array}{c}\text { Indirect } \\
\text { Influence }\end{array}$ & $\begin{array}{c}\text { Origin } \\
\text { al } \\
\text { Sample } \\
(\mathbf{O})\end{array}$ & $\begin{array}{c}\text { T } \\
\text { Statistic } \\
\mathbf{S}\end{array}$ & $\begin{array}{c}\mathbf{P} \\
\text { Value } \\
\mathbf{S}\end{array}$ & Explain \\
\hline $\begin{array}{c}\text { Compensationn } \\
\rightarrow \text { Job } \\
\text { Satisfaction } \\
\text { Turnover } \\
\text { Intention }\end{array}$ & -0.271 & 2,650 & 0.008 & $\begin{array}{c}\text { Significa } \\
\text { nt } \\
\text { Negative } \\
\text { Influence }\end{array}$ \\
\hline $\begin{array}{c}\text { Workload } \rightarrow \text { Job } \\
\text { Satisfaction -> } \\
\text { Turnover } \\
\text { Intention }\end{array}$ & $-0,081$ & 1,741 & 0.082 & No effect \\
\hline
\end{tabular}

Table 4:- Indirect Effects

It is known that the value of $t$ statistics of the Compensation variable is 2.650 which is greater than the value of $\mathrm{t}$ table $=2.003$, and the value of P-Values $=0.008$ which is smaller than $\alpha=0.05$, meaning that Ha is accepted, that is, there is the influence of the Compensation variable $\left(\mathrm{X}_{1}\right)$ on the Turnover Intention variable $\left(\mathrm{Y}_{2}\right)$ through Job Satisfaction $\left(\mathrm{Y}_{1}\right)$ The coefficient value is negative that is $0,271(-0,406 \times 0,666)$ meaning that the Compensation variable $\left(\mathrm{X}_{1}\right)$ has a negative effect on the Turnover Intention variable $\left(\mathrm{Y}_{2}\right)$ through Job Satisfaction $\left(\mathrm{Y}_{1}\right)$ of $27.1 \%$. Thus, the hypothesis $\mathrm{H} 6$ in this study which states that "Compensation $\left(\mathrm{X}_{1}\right)$ has a significant effect on the Turnover Intention $\left(\mathrm{Y}_{2}\right)$ variable through the Job Satisfaction variable $\left(\mathrm{Y}_{1}\right)^{\prime}$ accepted.

The known value of $\mathrm{t}$ statistics for the Workload variable is 1,741 which is greater than the value of t table $=$ 2.003 , and the value of P-Values $=0.082$ is greater than $\alpha=$ 0.05 , meaning that $\mathrm{Ha}$ is rejected, ie there is no influence from the Workload variable $\left(\mathrm{X}_{2}\right)$ of the Turnover Intention variable $\left(\mathrm{Y}_{2}\right)$ through Job Satisfaction $\left(\mathrm{Y}_{1}\right)$. Thus, the hypothesis $\mathrm{H} 7$ in this study which states that "Workload $\left(\mathrm{X}_{2}\right)$ has a significant effect on the Turnover Intention $\left(\mathrm{Y}_{2}\right)$ variable through the variable Job Satisfaction $\left(\mathrm{Y}_{1}\right)^{\prime \prime}$ is rejected.

\section{MANAGERIAL IMPLICATIONS AND DISCUSSION}

\section{The Effect of Compensation on Job Satisfaction.}

Based on the hypothesis test in this study shows that compensation has a positive and significant effect on job satisfaction, which means that one way to increase employee job satisfaction is to guarantee compensation received by employees. This is consistent with previous research conducted by Rohmawati et al (2017) where compensation has a positive and significant effect on employee job satisfaction.

In this study the highest score on the compensation variable is in the indirect compensation dimension with the work dimension itself. This can mean that clinic employees need guarantees not only from direct compensation, but also indirect compensation such as health insurance, life insurance and old age insurance. It is understandable that clinic employees as front-line workers need to get these guarantees because of the high risk of work they face, especially when there are pandemic conditions. By ensuring health insurance, life insurance and old age insurance will affect employee satisfaction in doing their work.

The managerial implication carried out by PT Nayaka Era Husada Bekasi branch is to ensure that all clinic employees are registered and can exercise their rights in health insurance (BPJS Kesehatan) and old age insurance (BPJS Labor).

\section{- Effect of Workload on job satisfaction.}

Based on hypothesis testing in this study shows that Workload has a positive and significant effect on job satisfaction. The results of this study are supported by previous research conducted Pristianahadi and Nawangsari (2019) where workload greatly influences the turnover intention rate in PT. CN.In this study, the highest score is in the dimensions of physical demands related to promotion. Clinic staff, especially health workers, will definitely do the same thing every day in accordance with their competencies. However, the promotion opportunity provided by the company is an advantage that can increase employee job satisfaction.

Managerial implications that have been carried out by PT Nayaka Era Husada Bekasi branch is to provide opportunities for clinic employees both medical and nonmedical to enter the company's management team. So that promotional opportunities can also be obtained by each employee equally in accordance with applicable regulations.

\section{Effects of Compensation on Turnover Intention}

Based on hypothesis testing in this study shows that compensation has a negative and significant effect on turnover intention. This result is in accordance with previous research, namely Hayati et al (2017) where compensation significantly influences turnover intention.On this study achieved the highest score of indirect compensation dimensions to the mind to stop. As with the job satisfaction variable, indirect compensation also affects employees' 
thoughts about quitting their jobs. This means that if the employee feels no collateral other than direct income, the employee will think of quitting the job.

Managerial implication that the company has done is to provide monthly incentives the amount of which is determined by several points set by the company such as performance, complaints and timeliness of attendance. So the amount received by each employee can be different and varied each month.

\section{$>$ Effect of Workload on Turnover Intention.}

Based on the fourth hypothesis test in this study showed that the workload does not affect turnover intention. These results are not in accordance with research conducted by Widiawati et al (2017) where workload has a significant effect on turnover intention. However, research conducted by Zeytinoglu et al (2007) found that workload did not affect the turnover intention of part-time nurses in Canada. This means that in clinical employees, workload does not influence the high turnover intention. This can occur because of the similarities between the types of respondents in the study Zeytinoglu et al (2007) where the respondents are part time nurses. Whereas in this study, some respondents were part time,

\section{Effect of Job Satisfaction on Turnover Intention.}

Based on the fifth hypothesis test in this study shows that job satisfaction has a negative and significant effect on job satisfaction. This is consistent with the results of previous studies conducted by Kusumaningrum and Harsanti (2015) regarding job satisfaction with turnover intention of nurses inpatient installations.

Score the highest obtained on the variable job satisfaction to the variable turnover intention is the income or salary dimensions with the dimension of the desire to find another job. This means that if employees feel the salary or income, they earn is sufficient it will suppress the desire of employees to find other work.

\section{$>$ Effect of Compensation on Turnover Intentions through Job Satisfaction.}

Based on the sixth hypothesis test in this study shows that compensation has a negative effect on turnover intention through job satisfaction. The results of this hypothesis are supported by previous research conducted by Agustin (2018) that compensation has a negative and significant effect on turnover intention through job satisfaction. Direct and indirect effect hypothesis test shows that the value of the influence of Compensation on indirect turnover intention is through an intermediate variable Job Satisfaction is higher when compared directly or directly. Then the increase in compensation will affect employee job satisfaction so that it will reduce the turnover intention in clinical employees in the company.

Clinic employees in the majority of companies are medical workers who not only require direct compensation, but also indirect compensation such as health insurance and old age benefits such as non-clinical / managerial employees in the company.

\section{$>$ Effect of workload on turnover intention through job satisfaction.}

Based on the seventh hypothesis test in this study that workload does not affect turnover intention through job satisfaction. These results are not in accordance with research conducted by Permatasari (2019) that workload has a negative and significant effect on turnover intention through job satisfaction. However, in accordance with research on part-time nurses in Canadian hospitals conducted by Zeytinoglu et al (2007) that workload has no effect on turnover intention even through job satisfaction. Similar to the results in the fourth hypothesis, that there is no influence between workload on turnover intention, the results of the seventh hypothesis can also be in accordance with the results of research by Zeytinoglu et al (2007) where workload does not affect turnover intention through job satisfaction with part time nurses.

\section{CONCLUSION AND SUGGESTION}

\section{A. Conclusion}

Based on the results of the discussion of data analysis through proving the hypotheses of the problems discussed and explained in Chapter IV, it can be concluded from the following research:Compensation affects Job Satisfaction. The indirect compensation dimension has the highest correlation to the work dimension itself from the job satisfaction variable. While the lowest dimension of correlation is the indirect compensation dimension to the promotion dimension.

Workload influences job satisfaction. The dimension which has the highest correlation is the physical demand dimension to the promotion dimension. While the dimension that has the lowest correlation is the dimensions of the task demands of the promotion dimension.

Job satisfaction influences turnover intention, specifically through the income / salary dimension to the desire to find another job. This means that if employees have received the appropriate salary, their job satisfaction will increase and will affect turnover intention so that employees do not have the desire to find another job. While the dimension of the lowest value is the dimension of coworkers towards the desire to find another job.

Compensation affects turnover intention, especially in the indirect compensation dimension to the dimension of mind for stopping which has the highest correlation value. This means that the existence of indirect compensation can influence the minds of employees to quit their current jobs. While the indirect compensation dimension to the dimension of the desire to leave has the lowest correlation value.

Workload does not affect turnover intention. The dimensions of the task demand on the dimensions of the desire to leave the company have the highest correlation. This means that the number of tasks given to clinic 
employees can influence the desire of employees to leave the company. While the lowest correlation is in the dimensions of physical demands on the dimensions of the mind to stop, which means that the smaller working hours affect the minds of employees to quit their jobs.

Compensation has an influence on turnover intention through job satisfaction. In the results of this study found that the effect of compensation on turnover intention indirectly or through mediation has a smaller $t$ statistic value than directly. This means that to reduce turnover intention, companies do not need to increase job satisfaction first, but can directly improve employee compensation.

Workload has no influence on turnover intention through job satisfaction. In the results of this study it was concluded that the effect of workload on turnover intention indirectly or through job satisfaction has a $t$ value statistically smaller than $\mathrm{t}$ table, so in reducing turnover intention numbers there is no need to correct workload problems.

\section{B. Suggestion for the company}

Suggestions that I can give in this research for the company are as follows: company need to consider increasing compensation considering the results of this study indicate the effect of compensation on turnover intention is significant. Increasing compensation can be done not only by raising salaries, but companies can also provide additional incentives or bonuses within a certain period. Increased compensation can also be done by ensuring that employees receive insurance and pension guarantees. This compensation increase is also done to increase employee job satisfaction.

Company too need to pay attention to job satisfaction as a cause of high turnover intention rates, because job satisfaction as an independent variable is higher in correlation than job satisfaction as a mediating variable. This means that job satisfaction more influences the variable turnover intention independently than being a mediating variable. From the results of this study the factors that most influence employee job satisfaction are the compensation dimensions with the desire to find another job. From these results, to improve company job satisfaction can provide rewards to model or outstanding clinical employees. Companies can also consider giving bonuses to clinic employees with a certain service period, or giving free SKP to medical personnel.

In this study workload does not affect turnover intention, but workload positively affects employee job satisfaction. From the author's perspective this can occur because in the present situation with the corona virus pandemic, the number of patient visits to the clinic has decreased dramatically compared to before the pandemic. With this decline in visits, of course the workload felt by employees is reduced, but there is a feeling of worry that decreasing the number of visits means reducing satisfaction with their own work. For that the company needs to make a program such as a healthy visit where patients do not need to feel sick first to visit. It could also open a rapid test or swab test service by complying with applicable health protocols.

Job satisfaction affects turnover intention, where the highest correlation results are in the income or salary dimensions. To increase job satisfaction, companies can increase compensation both in terms of salary and benefits outside salary. Companies do not need to focus only on compensation, increased job satisfaction can also be done through the promotion system transparency or increased communication between supervision with clinical employees who are also on duty between clinic employees. Improved communication can be done by holding outings, leadership training and so on. With a good relationship between the employee and his supervisor and his colleagues, will affect the employee's satisfaction.

\section{Suggestion for future research}

Considering this research has limitations, in the future the authors suggest that further research be conducted on the effect of compensation and workload on turnover intention through job satisfaction in the business and other service sectors so that it can provide even greater insight for all of us.

\section{REFERENCES}

[1]. Alsaraireh, Faris. Griffin, Mary. TQ, Ziehm, Scott. R., Fitzpatrick, Joyce. J. (2014). Job Satisfaction and Turnover Intention among Jordanian Nurse in Psychiatric Units. International Journal of Mental Health Nursing. 23, 460-467.

[2]. Armstrong, Deborah. \& Zaza, Ibtissam. (2014). Turnover Intention among Information Technology Professionals: A Meta Analytical Perspective. Thirty Seventh International Conference of Information Systems. Aisle.aisnet.org. Dublin

[3]. Chen, ML, Su, ZY, Lo, CL, Chie, CH, Hu, YH, Shieh, TY (2013). An Empirical Study on the factors influencing the Turnover Intention of dentists in Hospitals in Taiwan. Journal of Dental Sciences xx. 113.

[4]. Colquitt., Lepine. \& Wesson (2009) Organizational Behavior. New York: McGraw-Hill

[5]. Dessler, Gary. (2011). Human Resources Management. Issue 14. Salemba Four Publishers. Jakarta.

[6]. Ghazawi, Issam. (2008). Job Satisfaction Antecedents and Consequences: A New Conceptual Framework and Research Agenda. The Business Review, Cambridge.

[7]. Ghozali, Imam and Hengky Latan. (2015). Concepts, Techniques, Applications Using Smart PLS 3.0 for Empirical Research. BP Undip. Semarang.

[8]. Green, Amy. E., Miller, Elizabeth. A., Aarons, Gregory, A. (2013). Transformational Leadership Moderates the Relationship Between Emotional Exhaustion and Turnover Intention Among Community Mental Health Providers. Community 
Mental Health Journal. August 2013, Vol 49, Issue 4. PP 373-379.

[9]. Halfhill, TR, Huff, JW, Johnson, DA, Ballentine, RD, \& Beyerlein, MM (2002). Interventions that work (and some that don't): An executive summary of the organizational change literature. In RL Lowman (Ed.), The California school of organizational studies: Handbook of organizational consulting psychology: A comprehensive guide to theory, skills, and techniques (pp. 619-644). San Francisco: Jossey-Bass.

[10]. Hanggraeni, Dewi. (2011). Human Resource Management, Jakarta: FE UI Indonesia Publishing Institute.

[11]. Hayati, Davoud. Charkhabi, Morteza. Kalantari, Dariush. De Paola, Francesco. (2015). The Effect of Pay Satisfaction on Turnover Intention Mediating Role of Job Satisfaction and Organizational Commitment. Journal of International Management Studies. Vol 15. No 2. E-ISSN: 2378-9557

[12]. Hesarika, Adelia. (2018). The Effect of Job Stress and Job Satisfaction on Turnover Intention of Inpatient Nurses in 2017 (Study at Mother Thamrin General Hospital Medan). Simantek Scientific Journal Vol 2 No. 2 April 2018. ISSN 2550-0414.

[13]. Irwandy. (2007). Factors Related to the Nurse's Workload in the Inpatient Unit of Dadi Makassar General Hospital. Makassar; Hasanuddin University.

[14]. Ivancevich, G. and Konopaske, D. (2013). Organizations, Behavior, Structure, Process. 12th Edition.

[15]. Jogiyanto, Hartono. (2011). Business Research Methodology: Misguided and Experiences. BPFE. Yogyakarta.

[16]. Kusumaningrum, Dini., Harsanti, Intaglia. (2015). Contribution of Job Satisfaction to Turnover Intentions in nurses in the inpatient ward. Proceedings of the PESAT. Vol 6. October 2015. ISSN: 1858-2559.

[17]. Labrage, JL, Gloe, Donna., McEnroe, DM, Konstantinos, Kostas., Colet, Paolo. (2018). Factors Influencing Turnover Intention Among Registered Nurses in Samar Philippines. Applied Nursing Research 39.

[18]. Luthans, Fred. (2011). Behavior Organizations. Tenth Edition. The McGraw-Hill Companies, Inc.

[19]. Manurung, Mona. (2012). Analysis of the Effect of Job Stress and Job Satisfaction on Employee Turnover Intention (Study on Widya Husada Semarang Stikes). E-prints.undip.ac.id.

[20]. Mello, JA (2011). Strategic Human Resources Management. 2nd Edition.homson.

[21]. Mobley, WH (2011). Employee Substitution: Cause, Effect, and Control (Trans). Jakarta: PT Pustaka Binama Pressindo.

[22]. Mobley, W. H, Horner, SO \& Hollingsworth, AT (1978). An Evaluation of Precursors of Hospital Employee Turnover. Journal of Applied Psychology. 63, 408-414.

[23]. Munandar, AS (2001). Industrial and Organizational Psychology. Jakarta: UI.

[24]. Orvis, KA, Dudley, NM, \& Cortina, JM (2008). Conscientiousness and reactions to psychological contract breach: a longitudinal field study. Journal of Applied Psychology, 93, 1183-93.

[25]. Porter, LW, Steers, RM, Mowday, RT (2013). Employee: Linkage Organizations, The Psychology of Commitment, Absenteeism and Turnover. Organizational and Occupational Psychological Series, 80, 151-176.

[26]. Pristianahadi, D. P. \& Nawangsari, L. C. (2019). The Effect of Work Load and CareerDevelopment with Work Satisfaction as aMediator for Turnover Intention in PT. CN. International Journal of Innovative Science and Research Technology, Volume 4, Issue 7, July 2019.

[27]. Putra, Achmad Syukriansyah. (2012). Analysis of the Effect of Workloads on the Performance of Employees in the Marketing and Credit Division of PT WOM Finance Depok Branch. Journal of Indonesian Management Study.

[28]. Raymond, Christian; Hatane, Samuel; Hutabarat, Julianus. (2015). Analysis of Quality of Human Resources, Service Quality, Organizational Performance, Community Trust and Community Satisfaction (Case Study: Population and Civil Registry Office of Nabire Regency). Journal of Industrial Technology and Management (JTMI). Vol 1 , No 1 .

[29]. Rivai, V and Sagala, EJ (2009). Human Resource Management For Companies. Rajawali Press. Jakarta

[30]. Robbins, Stephen and Judge. (2015). Organizational Behavior. Sixteenth Edition. Pearson Education, Inc. New Jersey.

[31]. Rohmawati, Beautiful. Yulianeu. Wulan, HS, Dhiana, P. (2017). Effect of Transformational Leadership Style and Compensation on Turnover Intentions mediated by Job Satisfaction. Jurnal.unpand.ac.id

[32]. Rubles, Mohammad, RB, Hung Kee, Daisy. M. (2015). High Commitment Compensation Practices and Employee Turnover, mediating the role of Job Satisfaction. Mediterranian Journal of Social Sciences Vol 6 No 6 December 2015. ISSN 2039-9340.

[33]. Secretary General of the Ministry of Home Affairs. Permendagri Number 12. (2010). Guidelines for Analysis of Workload in the Ministry of Home Affairs and Local Governments.

[34]. Simamora, Henry. (2010). Human Resource Management Third Edition. First printing. Yogyakarta: STIE YKPN.

[35]. Sudiharto. (2011). Time Study of Workload and Its Relationship with Performance of Nurses in Dahlia Inpatient Room of the Regional Hospital (BRSD) Raa Soewondo Pati. Dissertation. Diponegoro University.

[36]. Sugiyono (2017). Quantitative, Qualitative, and R\&D Research Methods. Alfabeta: Bandung.

[37]. Sunyoto, Danang. (2012). Human Resource Management. Yogyakarta: CAPS.

[38]. Suputra, PMA, Yuesti, Anik. Sudja, IN (2019). The Effect of Work Satisfaction, Organizational Commitment and Workload on PT Bank Rakyat Indonesia (PERSERO) Tbk Sekanca Gajah Mada Unit. IJSEGCE. Vol 2. No 1. March 2019. ISSN: 26563037. 
[39]. Suwandi \& N. Indriantoro. (2009). Testing of the Pasewark and Strawser Turnover Model: Empirical Studies in the Public Accounting Environment. Indonesian Accounting Research Journal, Vol. 2, 173195.

[40]. Tarwaka. (2010). Industrial Ergonomics. Surakarta: Hope Press

[41]. Vinita, D., Ken, P., Ann, M. (2009). The Impact of Work Stress and Job Satisfaction on Turnover Intentions. Informa Healthcare Journal.

[42]. Wang, Qingjuan; Li, Rui; Wang, Ailing. (2019). The Impact of Promotion of Justice on Occupational Health and Turnover Intention. Proceedings of the 2019 International Conference on Management, Education Technology and Economics (ICMETE). ISSN: 23525428.

[43]. Putri, Dwiyan., Christina, Lenny (2019) The Effect of Work Load and Career Development with Work Satisfaction as a Mediator for Turnover Intention in PT. CN. Mercu Buana University. Jakarta

[44]. Widiawati, Firda., Amboningtyas, Dheasey., Rakanita, AM, Warso, MM (2017). Effect of Workload, Work Stress on Turnover Intention of employees of PT Geogiven Visi Mandiri Semarang. Unpand.ac.id.

[45]. Yamin, Sofyan and Heri Kurniawan. (2011). New Generation Processes Research Data with Partial Least Square Path Modeling. Salemba Infotek. Jakarta

[46]. Zeytinoglu, IU, Denton, M., Davies, S., Baumann, A., Blythe, J., Boos, L. (2007). Deteriorated External Work Environment, Heavy Workload and Nurses' Job Satisfaction and Turnover Intention. Canadian Public Policy-Analyze De Politiques. Vol XXXIII. 